\title{
A review of adaptive overcurrent protection in distribution networks with integration of distributed energy resources
}

\author{
Nur Aisyah Mohd Yusof ${ }^{1}$, Zaipatimah Ali ${ }^{2}$, Mohd Zainal Abidin Ab Kadir \\ ${ }^{1,2}$ Department of Electrical Power Engineering, Universiti Tenaga Nasional, Malaysia \\ ${ }^{3}$ Institute of Power Engineering, Universiti Tenaga Nasional, Malaysia
}

\begin{tabular}{l} 
Article Info \\
\hline Article history: \\
Received Dec 14, 2019 \\
Revised Feb 3, 2020 \\
Accepted Feb 18, 2020 \\
\hline Keywords: \\
Adaptive overcurrent \\
Distributed energy resources \\
Distribution network \\
Fault detection \\
Network topology \\
\hline
\end{tabular}

\begin{abstract}
This paper presents a review of an adaptive overcurrent protection scheme in a distribution network with the integration of distributed energy resources. The rapid integration of distributed energy resources brings challenges to the existing overcurrent protection system. The impacts are change in fault current magnitude and direction of current flow from radial to the multi-source dynamic network, which causes changes in network topology, inaccurate fault detection, and loss of coordination among protection systems. In this paper, the solution identified for reliable operation of overcurrent protection in the distribution network are network topology estimation, fault detection, and adaptive coordination.
\end{abstract}

Copyright (C) 2020 Institute of Advanced Engineering and Science. All rights reserved.

\section{Corresponding Author:}

Nur Aisyah Mohd Yusof,

Department of Electrical Power Engineering,

Universiti Tenaga Nasional,

Putrajaya Campus, 43000 Kajang Selangor, Malaysia.

Email: naisyah.myusof@gmail.com

\section{INTRODUCTION}

Distributed energy resources (DER) have received much attention as it offers a great opportunity to utilize the indigenous renewable energy resources as well as create flexibility in generation and distribution. A DER is a term applied to a wide variety of technologies including distributed generation (DG), microgrids, photovoltaic (PV), energy efficiency (EE), smart inverters, battery energy storage and electric vehicle (EV) [1-4]. The benefits including cost saving to consumer, a reduction in emission, reliability assurance, and adequate power quality [5-12]. Despite all the benefits, interconnecting DER brings challenges to the existing protection scheme in the distribution network.

The advancement of distribution networks has posed challenges to long-established protection schemes including feeder protection blinding, sympathetic tripping of adjacent feeder relays, coordination problems between reclosers and downstream fuses, failed auto-reclosing and unintentional islanding [13, 14]. The integration of DER in distribution networks would change the distribution network topology creating it a multi-source dynamic network with bi-directional current flow $[15,16]$. Besides that, integration of DER causes the variation in the fault current level in the network and disturb the coordination between relays. Numerous studies on the impacts of DER on the existing protection of distribution networks have been analysed by the researcher [17-23].

The most widely used form of protection in the distribution network is overcurrent protection $[24,25]$. Directional overcurrent relays (DOCR) are normally used for the protection of a distribution network and also as secondary protection of the transmission networks [26]. However, the presence of DER resulting in the maloperation of traditional DOCR in a distribution network. Two approaches have been identified for protection in the distribution network with the presence of DER [27]. The first approach is 
based on the conventional protection scheme with minimum changes, easy to implement and does not involve any modification in the existing distribution network. However, this approach demotes the capability of DER as backup and alternative sources as well as jeopardize fault detection and isolation. The second approach based on the adaptive protection scheme, which involves the modification of the protection setting according to the condition of the network. This approach allows a dynamic change in setting corresponding with the current operating condition of distribution networks.

The key operation of overcurrent protection depends on the protection settings. The integration of DER in the distribution network requires a change in the settings of overcurrent protection. Hence, an adaptive protection scheme is required to identify the protection parameter settings according to the prevailing system condition for accurate operation of overcurrent protection. Various strategies for adaptive protection proposed by the researcher and these strategies can be categorized into three main strategies, which are identified as network topology estimation, fault detection, and adaptive coordination.

The objective of this paper is to presents an overview of the adaptive overcurrent protection scheme with the integration of DER. This paper is structured according to the following section: Section 2 presents the impact of DER on overcurrent protection. Section 3 presents adaptive overcurrent protection and Section 4 provides discussion on strategies of the adaptive overcurrent protection considering integration of DER. Lastly, section 5 concludes the paper.

\section{IMPACT OF DER ON OVERCURRENT PROTECTION}

The introduction of DER in the distribution network provides challenges to existing overcurrent protection schemes. Numerous studies and analysis are performed on the impact of DER on existing overcurrent protection. Three major challenges are highlighted which are a change in network topology, fault current contribution from DER and miscoordination between protection relays.

\subsection{Change in network topology}

Conventional distribution networks with traditional protection schemes are initially design based on the passive paradigm and only protect in unidirectional power flow. The integration of DER has changed the networks to be active paradigm and traditional protection scheme is ineffective for the network. The growing DER penetration in distribution network combined with the variable operation mode of the microgrid as well as the connection of DER, require a change in the structure and topology of protection scheme owning to change in the power flow direction [28-30]. The presence of DER can cause sympathetic tripping happens. Hence, modifying in relay setting and characteristics of overcurrent protection in distribution networks is required according to the change in the network topology.

\subsection{Fault current contribution}

Fault current contribution become major concern in the power system. Integration of DER not only alter the power flow in the distribution networks but also affect the fault current during the event of disturbance [31]. The penetration of DER in distribution network has significantly changed the magnitude and the direction of fault currents. The variation of fault level are depends on the technology of DER (synchronous machine DG or inverter based DG), DER capacity, grid impedance, as well as the location of the point of common coupling (PCC) $[32,33]$. The amount of fault current contributed by DER varies widely [32, 34]. Generally, DER are connected with network via power converter, so the fault behaviour are depends on converter controller and its design parameter [35]. The contribution of Inverter Based Distributed Generation (IBDG) to the system's fault current level is the lowest [33]. The integration of DER cause the increase in equivalent impedance of the network, which result decrease in the fault current level [36-41].

\subsection{Miscoordination}

The miscoordination between two adjacent feeders can occur when DER are introduced in the distribution networks. Losing the protection coordination may cause the substantial problem in power system reliability and outage of large number of distribution feeder [42]. The traditional coordination of protection system are designed in radial systems is based on time current curves (TCC). Both downstream and upstream overcurrent relay should be able to discover the fault current, the downstream relay should operate faster than the upstream one. Hence, operating time corresponding to the downstream relay must be lower than the upstream relay, keeping an arrow delay time for the primary relay to isolate the fault. 


\section{ADAPTIVE OVERCURRENT PROTECTION}

Adaptive protection has been established since 1980s [43]. It was empowered with the increase of computer-based relays [44]. This enable to change the relay setting corresponding to changing the system condition. Adaptive protection are defined as an online activity that modifies the protective devices corresponding to the change in system conditions or requirements [43]. The adaptive protection can be divided into adaptive protection device and adaptive protection system according to its function and information used [45].

\subsection{Network topology}

Adaptive overcurrent protection based on identified the network topology strategies defined as a change of system condition, either under operation of grid connected or islanded mode and operation of DER (connect or disconnect) in the network. The settings of overcurrent relay revised according to the change of network topology. Communication system plays important role in this scheme as to provide information for the change in relay settings. However, there are an adaptive scheme only using local information to update the relay setting [46]. Hence, the scheme can be divide either by using local information or communication module.

Author in [46] have proposed the adaptive scheme based on conventional overcurrent protection with detection operating states and the faulted section detection. The proposed scheme have different set of relay settings for grid connected and islanded mode based on predefined protection settings. The scheme uses only local information to update the relay settings. However, the proposed scheme not suitable with the advancement of technology as well as high penetration of DER in the system.

Hence, references in [47-56] have introduced solutions based on adaptive scheme concerning the adaption of overcurrent relay with change in network topology due to penetration of DER in power system. The author in [47] proposed method based on system topology detection to modify automatically relay trip parameter as defined by author in [46]. In this scheme, the new relay parameter calculated from the percentage change of fault currents with respect to power system without DER. However, this scheme may lead to loss of coordination and sympathetic tripping specifically with high penetration of DER. While, author in [48] proposed adaptive scheme which identifies the network topology by impedance level of the grid. The system operating state is identified by the use of a state detection device, thyristor which responsible to estimate the system equivalent impendence. The identification of network condition will update overcurrent relay settings.

In [49] and [50] an adaptive relaying algorithm for distribution feeders with wind farms is proposed. The adaptive algorithm in [49] depends on fault type and level, and it takes into account the generator output power. On the other hand, an algorithm that considers only the operational status of the WG is developed. In [50], the author proposed an adaptive relay settings considering the operation scenario of wind generators (WGs). Advanced distribution automation system (ADAS) activated the adaptive scheme by according to the operational status of line switches and WGs. The protection settings of all relays revised after performing short circuit analysis in order to achieve protection coordination for all relays.

The author in [51] have proposed adaptive scheme which adopt the measures in real time which could automatically identify the variation of parameters and modify the corresponding protection setting calculation. While, adaptive scheme of minimum pickup current are presented in [52]. The proposed technique established on update the overcurrent fault current based on fault current analysis.

Several research works have addressed adaptive protection scheme in microgrid with extensive communication to deal with these problems [53-55]. The scheme concern on the improvement of adaptive overcurrent relays which should operate correctly with respect to configuration changes, equipment outages and transient instability. However, the change in network configurations cause the variation of fault current which necessitation adaption of relay operating time.

Therefore, the author in [55] consider the critical clearing time for stability of generators when microgrid operates in grid-connected and islanded mode. The author in [56] have proposed adaptive scheme with considering the increasing of DER, introduction of active-network-management (ANM) and operation of islanded mode. The scheme utilized centralized approach where setting calculations and commands are performed by master controller through communication links. Therefore, whenever there is a significant change in network, new protection settings can applied and update directly to the relay.

\subsection{Fault detection}

Fault detection is a very important issue to consider in the power systems in order to ensure safety, reliability and to avoid accidents, damages to equipment and undesired blackouts. The effectiveness of overcurrent protection is depends on the accurate fault signal estimation. When fault occur, overcurrent relay must responds in fast and selective isolation of fault in anywhere along the distribution feeders. However, 
the fault occurrence in distribution network with the inclusion of DER may distort the fault signals and introduce the decaying dc-component and harmonics. Thus, it making a process of tracking the phasor very challenging. Hence, suitable phasor estimation algorithms are necessary for fast and efficient signal estimation for fault detection. The accurate fault signal estimation can achieved using mathematical function such as Fourier Transform, The venin Equivalent and Mathematical Morphology (MM) technique.

The author in [32] have proposed a fast recursive discrete Fourier transform (FRDFT) algorithm for efficient fundamental tracking of varying power system signal. The FRDFT algorithm had been equipped with directional element to implement different sets of protection settings for grid-connected and islanded mode. Besides, the FRDFT algorithm is embedded with a fuzzy-logic decision-making (FLDM) module in case of changing system conditions and varying DG penetration. The FRDFT algorithm has proved the efficient phasor computation. The technique enables sample-by-sample updating, which, in sequence, allows for the computation of a fine time-frequency resolution. In [33], the author proposed an adaptive overcurrent protection based on optimized thevenin equivalent parameters estimation. The proposed scheme is based on the local available measurement where the parameter of the thevenin equivalent circuit are estimated using the proposed estimation method. In this paper, inverter-interfaced distributed generator (IIDG) during fault is considered. Therefore, it is necessary to analyse the fault current from IIDG separately from the system.

Mathematical morphology (MM) widely used in signal processing. Author in [38] have presented a-MM based fault detection for adaptive overcurrent protection scheme. The proposed algorithm has built in DC-offset suppression capability and recursive least square error (RLSE) filter. The RLSE used for current phasor estimation to provide input for algorithm.

\subsection{Adaptive coordination}

Nowadays, with the large integration of DER in the distribution network, the chance of mis-coordination between relays increases. The optimal coordination becomes a very hard task as the network becomes complex and larger. The issue of optimal coordination with integration of DER have been addressed by author in [57-60]. Therefore, the possible solution to get the optimal coordination with considering the DER in the network is by use adaptive coordination. The adaptive coordination scheme adapts to system changes; new relays settings obtained as generation-level or system-topology changes. Many researcher are focused on optimal coordination problem only without consider the large integration of DER in the network.

There a few researcher presented adaptive coordination scheme for optimal coordination. For example, the author in [61] has proposed online adaptive technique without communication links for setting all relays in HV substations. The technique based on online estimation of short circuit currents for selection of overcurrent relay setting in order to achieve optimal coordination. Meanwhile, author in [62] has used adaptive scheme based on master computer as well as communication links for selection of protection settings to achieve the optimal relay coordination. In [63], the author has proposed an adaptive scheme which uses positive sequence and negative sequence components of fault current to achieve coordination between the primary and backup overcurrent relays

\section{DISCUSSION}

The impact of overcurrent protection due to integration of DER and the necessity of changing the relay settings to adapt the system condition is essential steps for the effective and accurate design of adaptive overcurrent protection. The possible risk can cause the blinding of protection or false tripping and deteriorates the reliability and stability of distribution networks. In order to realize adaptive scheme, relay settings must be satisfied and all constraint are fulfil as it can maintain the overcurrent protection network with increasing DER. Previous works of adaptive overcurrent protection scheme can be categorized into three group based on network topology estimation, fault detection, and adaptive coordination. The adaptive scheme is listed in Table 1 as references that would be great sources to design an adaptive overcurrent protection which versatile and robust with high penetration of DER. 
Table 1. Summary of adaptive overcurrent protection scheme

\begin{tabular}{|c|c|c|c|c|}
\hline $\begin{array}{l}\text { Adaptive } \\
\text { Scheme }\end{array}$ & Findings & Advantages & Disadvantages & Ref \\
\hline \multirow[t]{3}{*}{$\begin{array}{l}\text { Network } \\
\text { Topology }\end{array}$} & $\begin{array}{l}\text { The proposed scheme using local } \\
\text { information to update the relay settings. }\end{array}$ & $\begin{array}{l}\text { The relay setting are update by } \\
\text { detecting the operating states and } \\
\text { the faulted section. }\end{array}$ & $\begin{array}{l}\text { The method based on predefined } \\
\text { relay settings by local } \\
\text { information. }\end{array}$ & {$[46]$} \\
\hline & $\begin{array}{l}\text { The proposed scheme uses the } \\
\text { information from original system without } \\
\text { DG and compare with the percentage } \\
\text { variation of fault levels. }\end{array}$ & $\begin{array}{l}\text { Using PLC and master control as } \\
\text { communication system in this } \\
\text { scheme. }\end{array}$ & $\begin{array}{l}\text { The study case only consider } \\
\text { synchronous generator and wind } \\
\text { generator. }\end{array}$ & [47] \\
\hline & $\begin{array}{l}\text { The proposed scheme used method based } \\
\text { on the impedance level of the grid. }\end{array}$ & $\begin{array}{l}\text { This scheme doesn't require } \\
\text { communication system }\end{array}$ & $\begin{array}{l}\text { The performance may fail for } \\
\text { some operation conditions, such } \\
\text { as cannot identify the } \\
\text { reconnection of the DG to the grid }\end{array}$ & [48] \\
\hline \multirow[t]{8}{*}{$\begin{array}{l}\text { Network } \\
\text { Topology }\end{array}$} & $\begin{array}{l}\text { The proposed scheme based on consider } \\
\text { the type and level condition of fault. }\end{array}$ & $\begin{array}{l}\text { This scheme doesn't require } \\
\text { communication system. }\end{array}$ & $\begin{array}{l}\text { It takes into account the generator } \\
\text { output power. }\end{array}$ & [49] \\
\hline & $\begin{array}{l}\text { The proposed scheme based on monitor } \\
\text { the operational status of wind generator } \\
\text { and line switches }\end{array}$ & $\begin{array}{l}\text { Utilizes an advanced distribution } \\
\text { automation system (ADAS) }\end{array}$ & $\begin{array}{l}\text { Micro-grid can have synchronous } \\
\text { and inverter based generators } \\
\text { along with wind generators. }\end{array}$ & [50] \\
\hline & $\begin{array}{l}\text { The proposed scheme is based on } \\
\text { modification of relay settings where are } \\
\text { based on the sort of fault and system } \\
\text { impedance. }\end{array}$ & $\begin{array}{l}\text { The scheme offer satisfactory } \\
\text { solution which is independent of } \\
\text { number, size and location of DG } \\
\text { in the distribution network }\end{array}$ & $\begin{array}{l}\text { Not applicable for large scale of } \\
\text { DER. }\end{array}$ & [51] \\
\hline & $\begin{array}{l}\text { The proposed scheme update the } \\
\text { overcurrent pickup current based on fault } \\
\text { current analysis }\end{array}$ & Consider analysis in fault current & $\begin{array}{l}\text { Real time simulation is not } \\
\text { implemented to validate the } \\
\text { protection schemes }\end{array}$ & [52] \\
\hline & $\begin{array}{l}\text { The proposed scheme based on the } \\
\text { application of an artificial neural } \\
\text { network (ANN) by using real-time } \\
\text { synchronous phase measurement to } \\
\text { detect the state. The fault location is } \\
\text { estimated with the same measurement }\end{array}$ & Using artificial neural network & $\begin{array}{l}\text { Depending on communication } \\
\text { module and require huge resources } \\
\text { to store valuable data. }\end{array}$ & [53] \\
\hline & $\begin{array}{l}\text { The proposed scheme based on system } \\
\text { topological change for distribution } \\
\text { network with DG. }\end{array}$ & $\begin{array}{l}\text { This scheme takes into account } \\
\text { general protection requirements, } \\
\text { impacts of DG on protection } \\
\text { system and protection } \\
\text { coordination. }\end{array}$ & $\begin{array}{l}\text { All faults, abnormal operating } \\
\text { conditions and system } \\
\text { configurations based on pre- } \\
\text { determined condition. }\end{array}$ & [54] \\
\hline & $\begin{array}{l}\text { The proposed scheme based on adaptive } \\
\text { scheme for microgrid with consider the } \\
\text { critical clearing time for stability of } \\
\text { generator }\end{array}$ & $\begin{array}{l}\text { This scheme is adaptively for } \\
\text { critical clearing time }\end{array}$ & $\begin{array}{l}\text { Require huge resources to store the } \\
\text { offline data }\end{array}$ & [55] \\
\hline & $\begin{array}{l}\text { The proposed scheme using IEC- } 61850 \\
\text { communication and tested in hardware- } \\
\text { in-the-loop laboratory facility }\end{array}$ & $\begin{array}{l}\text { The protection settings calculated } \\
\text { in real time. }\end{array}$ & $\begin{array}{l}\text { Need to obtain the information of } \\
\text { voltage. }\end{array}$ & [56] \\
\hline \multirow[t]{4}{*}{$\begin{array}{l}\text { Fault } \\
\text { detection } \\
\text { technique }\end{array}$} & $\begin{array}{l}\text { The scheme is based on online } \\
\text { calculation method of fault current } \\
\text { corresponding with the system operation } \\
\text { conditions }\end{array}$ & $\begin{array}{l}\text { Using local measurement without } \\
\text { communication module }\end{array}$ & $\begin{array}{l}\text { Cannot be implement for large } \\
\text { scale of DER and take a long time } \\
\text { for isolation of fault. }\end{array}$ & [64] \\
\hline & $\begin{array}{l}\text { The proposed FRDFT algorithm is for } \\
\text { efficient and accurate estimation of fault } \\
\text { signal. Fuzzy logic controller is to set } \\
\text { relay trip settings. }\end{array}$ & $\begin{array}{l}\text { Efficient in fundamental tracking } \\
\text { of varying power system signal }\end{array}$ & $\begin{array}{l}\text { Applicable only for radial systems } \\
\text { and is not feasible for meshed } \\
\text { networks }\end{array}$ & [65] \\
\hline & $\begin{array}{l}\text { The proposed algorithm based on the } \\
\text { wavelet transform, overcurrent function } \\
\text { were reproduced through scaling } \\
\text { coefficient energy. }\end{array}$ & $\begin{array}{l}\text { Provide a real time detection of } \\
\text { fault inception time for minimize } \\
\text { the relay operating time }\end{array}$ & $\begin{array}{l}\text { Concentrate only on the } \\
\text { faults occurring downstream to the } \\
\text { DER-source }\end{array}$ & [66] \\
\hline & $\begin{array}{l}\text { The algorithm has built in dc-offset } \\
\text { suppression capability and RSLE filter. } \\
\text { Mathematical Morphology used to filter } \\
\text { the current }\end{array}$ & $\begin{array}{l}\text { The proposed scheme can } \\
\text { dynamically update the relay } \\
\text { settings. }\end{array}$ & $\begin{array}{l}\text { The proposed scheme only } \\
\text { applicable for radial network. }\end{array}$ & [67] \\
\hline \multirow[t]{3}{*}{$\begin{array}{l}\text { Adaptive } \\
\text { Coordination }\end{array}$} & $\begin{array}{l}\text { The adaptive scheme proposed by } \\
\text { calculating the three-phase fault current } \\
\text { at the relay bus for the changed system } \\
\text { topology. }\end{array}$ & $\begin{array}{l}\text { The proposed scheme for } \\
\text { microgrid consider both rotating } \\
\text { and inverter based distributed } \\
\text { generation systems (DGs) and } \\
\text { use only local information to } \\
\text { update relay setting }\end{array}$ & $\begin{array}{l}\text { Require sample of some voltage } \\
\text { and current phasors on the high } \\
\text { voltage bus of the substation for } \\
\text { the scheme }\end{array}$ & [61] \\
\hline & $\begin{array}{l}\text { The scheme is adapt to system changed } \\
\text { where new relays settings obtained as } \\
\text { changed in network topology by using } \\
\text { master computer. }\end{array}$ & $\begin{array}{l}\text { The proposed scheme achieve } \\
\text { optimal coordination using } \\
\text { Artificial Bee Colony (ABC) }\end{array}$ & $\begin{array}{l}\text { The proposed scheme required } \\
\text { communication links. }\end{array}$ & [62] \\
\hline & $\begin{array}{l}\text { The technique based on positive } \\
\text { sequence and negative sequence } \\
\text { components of fault current to } \\
\text { coordinate primary and backup relay }\end{array}$ & $\begin{array}{l}\text { The proposed scheme consider } \\
\text { technique for the microgrid } \\
\text { having both rotating and inverter } \\
\text { based DG. }\end{array}$ & $\begin{array}{l}\text { The proposed scheme consider } \\
\text { phase fails under critical condition } \\
\text { like single-pole tripping and line to } \\
\text { ground fault with variable fault } \\
\text { resistance. }\end{array}$ & [63] \\
\hline
\end{tabular}




\section{CONCLUSION}

This paper presented an overview of an adaptive overcurrent protection strategy to overcome the issue regarding the integration of DER in distribution network. The issue arise due to rapid integration of distributed energy resources in distribution network including network topology changes, inaccurate fault detection and miscoordination among protection system because of change in current magnitude and direction of current flow. The key operation of overcurrent protection is contingent on its protection settings. Adaptive scheme is vital for overcurrent protection as adaptive scheme adapts with system changing. In this study, the strategies for adaptive overcurrent protection in distribution networks are presented. Network topology was identified as a solution for operation of overcurrent protection in distribution networks. Fault detection was an effective strategy for accurate fault current estimation in distribution network. Adaptive coordination is the key strategy for optimal coordination for overcurrent protection with the rapid integration of distributed energy resources.

\section{ACKNOWLEDGEMENTS} possible.

This work was supported by UNITEN for providing the funding, facilities and making this research

\section{REFERENCES}

[1] O. Olatunde and H. A. Rahman, "Allocation of distributed generation and capacitor banks in distribution system," Indonesian Journal of Electrical Engineering and Computer Science (IJEECS), vol. 13, no. 2, pp. 437-446, February 2019.

[2] M. Gaspari and A. Lorenzoni, "The governance for distributed energy resources in the Italian electricity market: A driver for innovation?," Renewable and Sustainable Energy Reviews, vol. 82, pp. 3623-3632, February 2018.

[3] K. Malmedal, B. Kroposki, and P. K. Sen, "Distributed energy resources and renewable energy in distribution systems: Protection considerations and penetration levels," 2008 IEEE Industry Applications Society Annual Meeting, Edmonton, AB, pp. 1-8, 2008.

[4] T. Adefarati and R. C. Bansal, "Integration of renewable distributed generators into the distribution system: a review," IET Renew. Power Gener., vol. 10, no. 7, pp. 873-884, 2016.

[5] Z. Hisham, H. Hashim, Z. Shukri, and Z. Ishak, "Evaluation of protective relaying reliability in renewable energy environment," Indonesian Journal of Electrical Engineering and Computer Science (IJEECS), vol. 8, no. 2, pp. 407413, 2017.

[6] M. Abdelbadea, T. A. Boghdady, D. K. Ibrahim, and D. K. Ibrahim, "Enhancing active radial distribution networks by optimal sizing and placement of DGs using modified crow search algorithm," Indonesian Journal of Electrical Engineering and Computer Science (IJEECS), vol. 16, no. 3, pp. 1179-1188, December 2019.

[7] P. Basak, S. Chowdhury, S. Halder Nee Dey, and S. P. Chowdhury, "A literature review on integration of distributed energy resources in the perspective of control, protection and stability of microgrid," Renewable and Sustainable Energy Reviews, vol. 16, no. 8, pp. 5545-5556, 2012.

[8] M. F. Akorede, H. Hizam, and E. Pouresmaeil, "Distributed energy resources and benefits to the environment," Renewable and Sustainable Energy Reviews, vol. 14, no. 2, pp. 724-734, February 2010.

[9] A. Moreno-Munoz, J. J. G. De-La-Rosa, M. A. Lopez-Rodriguez, J. M. Flores-Arias, F. J. Bellido-Outerino, and M. Ruiz-De-Adana, "Improvement of power quality using distributed generation," International Journal of Electrical Power \& Energy Systems, vol. 32, no. 10, pp. 1069-1076, December 2010.

[10] Z. Li, M. Shahidehpour, A. Alabdulwahab, and Y. Al-Turki, "Valuation of distributed energy resources in active distribution networks," The Electricity Journal, vol. 32, no. 4, pp. 27-36, May 2019.

[11] Barney L. Capehart, "Distributed Energy Resources (DER) | WBDG - Whole Building Design Guide," Whole Building Design Guide, 2016. [Online]. Available: https://www.wbdg.org/resources/distributed-energy-resourcesder. [Accessed: 09-Jan-2019].

[12] G. Allan, I. Eromenko, M. Gilmartin, I. Kockar, and P. McGregor, "The economics of distributed energy generation: A literature review," Renewable and Sustainable Energy Reviews, vol. 42, pp. 543-556, February 2015.

[13] V. Telukunta, J. Pradhan, A. Agrawal, M. Singh, and S. G. Srivani, "Protection challenges under bulk penetration of renewable energy resources in power systems: A review," CSEE Journal Power Energy System, vol. 3, no. 4, pp. 365-379, 2017.

[14] S. Conti, "Analysis of distribution network protection issues in presence of dispersed generation," Electr. Power System Research, vol. 79, no. 1, pp. 49-56, January 2009.

[15] N. Rezaei and M.-R. Haghifam, "Protection scheme for a distribution system with distributed generation using neural networks," International Journal of Electrical Power \& Energy Systems, vol. 30, no. 4, pp. 235-241, May 2008.

[16] R. S. Rao, K. Ravindra, K. Satish, and S. V. L. Narasimham, "Power loss minimization in distribution system using network reconfiguration in the presence of distributed generation," in IEEE Transactions on Power Systems, vol. 28, no. 1, pp. 317-325, February 2013.

[17] S.-E. Razavi et al., "Impact of distributed generation on protection and voltage regulation of distribution systems: A review," Renewable and Sustainable Energy Reviews, vol. 105, pp. 157-167, May 2019. 
[18] S. A. M. Javadian, M.-R. Haghifam, M. Fotuhi Firoozabad, and S. M. T. Bathaee, “Analysis of protection system's risk in distribution networks with DG," International Journal of Electrical Power \& Energy Systems, vol. 44, no. 1, pp. 688-695, January 2013.

[19] S. Peng et al., "Comprehensive evaluation of impacts of distributed generation integration in distribution network," IOP Conf. Ser. Earth Environ. Sci., vol. 133, no. 1, p. 012010, Apr. 2018.

[20] P. T. Manditereza and R. Bansal, "Renewable distributed generation: The hidden challenges - A review from the protection perspective," Renewable and Sustainable Energy Reviews, vol. 58, pp. 1457-1465, May 2016.

[21] M. Singh, "Protection coordination in distribution systems with and without distributed energy resources- a review," Singh Protection and Control of Modern Power System, vol. 2, no. 1, pp. 2-27, 2017.

[22] E. Ghiani and G. Pisano, "Impact of Renewable Energy Sources and Energy Storage Technologies on the Operation and Planning of Smart Distribution Networks," Operation of Distributed Energy Resources in Smart Distribution Networks, pp. 25-48, 2018.

[23] S. A. A. Shahriari, A. Y. Varjani, and M. R. Haghifam, "Cost reduction of distribution network protection in presence of distributed generation using optimized fault current limiter allocation," in International Journal of Electrical Power \& Energy Systems, vol. 43, no. 1, pp. 1453-1459, December 2012.

[24] B. Ram and D. N. Vishwakarma, "Power System Protection and Switchgear," McGraw-Hill Professional Publishing; UK ed. edition, 2001.

[25] A. Mahari and H. Seyedi, "An analytic approach for optimal coordination of overcurrent relays," IET Gener. Transm. Distrib., vol. 7, no. 7, pp. 674-680, Jul. 2013.

[26] C. V. C. V. R. Aranke, "A Review on Impact of Distributed Generation on Directional Overcurrent Relay Coordination,” Int. Conf. Cond. Assess. Tech. Electr. System, pp. 44-49, 2017.

[27] M. Norshahrani et al., "Progress on Protection Strategies to Mitigate the Impact of Renewable Distributed Generation on Distribution Systems," Energies, vol. 10, no. 11, p. 1864, Nov. 2017.

[28] H. C. Kiliçkiran, İ. Şengör, H. Akdemir, B. Kekezoğlu, O. Erdinç, and N. G. Paterakis, "Power system protection with digital overcurrent relays: A review of non-standard characteristics," Electr. Power System Research, vol. 164, pp. 89-102, November 2018.

[29] N. H. V. Papaspilotopoulos, G. Korres, "An Adaptive Protection Infrastructure for Modern Distribution Grids with Distributed Generation," Cigre Science Engineering, pp. 125-132, 2016.

[30] A. A. Salam, A. Mohamed, and M. A. Hannan, "Technical Challenges On Microgrids," ARPN Journal of Engineering and Applied Sciences, vol. 3, no. 6, pp. 64-69, December 2008.

[31] N. Z. Mohamad, A. F. Abidin, and I. Musirin, "Detection of fault during power swing in test system interconnected with DG," Indonesian Journal of Electrical Engineering and Computer science (IJEECS), vol. 16, no. 2, pp. 577585, November 2019.

[32] V. A. Papaspiliotopoulos, G. N. Korres and N. D. Hatziargyriou, "Adverse impact of distributed generation on protection of the Hellenic MV network - recommendations for protection scheme upgrade," in CIRED - Open Access Proceedings Journal, vol. 2017, no. 1, pp. 934-938, October 2017.

[33] A. Darwish, A. S. Abdel-Khalik, A. Elserougi, S. Ahmed, and A. Massoud, "Fault current contribution scenarios for grid-connected voltage source inverter-based distributed generation with an LCL filter," Electric Power Systems Research, vol. 104, pp. 93-103, November 2013.

[34] R. A. Walling, R. Saint, R. C. Dugan, J. Burke, and L. A. Kojovic, "Summary of Distributed Resources Impact on Power Delivery Systems,” IEEE Transactions on Power Delivery, vol. 23, no. 3, pp. 1636-1644, July 2008.

[35] S. C. Ilik and A. B. Arsoy, "Effects of Distributed Generation on Overcurrent Relay Coordination and an Adaptive Protection Scheme," IOP Conf. Ser. Earth Environ. Sci., vol. 73, no. 1, 2017.

[36] N. Nimpitiwan, G. T. Heydt, R. Ayyanar, and S. Suryanarayanan, "Fault Current Contribution From Synchronous Machine and Inverter Based Distributed Generators," IEEE Transactions on Power Delivery, vol. 22, no. 1, pp. 634641, January 2007.

[37] T. M. Masaud and R. D. Mistry, "Fault current contribution of Renewable Distributed Generation: An overview and key issues," in 2016 IEEE Conference on Technologies for Sustainability (SusTech), pp. 229-234, 2016.

[38] A. Z. Adnan, M. E. Yusoff, and H. Hashim, "Analysis on the impact of renewable energy to power system fault level," Indonesian Journal of Electrical Engineering and Computer science (IJEECS), vol. 11, no. 2, pp. 652-657, 2018.

[39] H. Zayandehroodi, A. Mohamed, H. Shareef, M. Farhoodnea, and M. Mohammadjafari, "Effect of Renewable Distributed Generators on the Fault Current Level of the Power Distribution Systems," in Advanced Materials Research, vol. 622, pp. 1882-1886, January 2013.

[40] A. H. Osman, M. S. Hassan, and M. Sulaiman, "Communication-based Adaptive Protection for Distribution Systems Penetrated with Distributed Generators," Electr. Power Components Syst., vol. 43, no. 5, pp. 556-565, Mar. 2015.

[41] H. Wan, K. K. Li, and K. P. Wong, "An adaptive multiagent approach to protection relay coordination with distributed generators in industrial power distribution system," IEEE Trans. Ind. Appl., vol. 46, no. 5, pp. 2118-2124, 2010.

[42] F. Namdari and S. Samadinasab, "A New Method for Optimal Coordination of Overcurrent Relays Considering the Communication Channels Constraints," Indonesian Journal of Electrical Engineering and Computer science (IJEECS), vol. 1, no. 1, pp. 17-30, January 2016.

[43] G. D. Rockefeller, C. L. Wagner, J. R. Linders, K. L. Hicks, and D. T. Rizy, “Adaptive transmission relaying concepts for improved performance," in IEEE Transactions on Power Delivery, vol. 3, no. 4, pp. 1446-1458, 1988.

[44] J. A. Kumar, S. S. Venkata, and M. J. Damborg, "Adaptive transmission protection: concepts and computational issues,” in IEEE Transactions on Power Delivery, vol. 4, no. 1, pp. 177-185, Jan. 1989. 
[45] V. Y. Patil and G. B. Saunshi, "An Overview on Adaptive Protection in Power System," International Journal of Emerging Technology and Advanced Engineering vol. 4, no. 4, pp. 396-400, April 2014.

[46] P. Mahat, Z. Chen, B. Bak-Jensen, and C. L. Bak, "A simple adaptive overcurrent protection of distribution systems with distributed generation," IEEE Trans. Smart Grid, vol. 2, no. 3, pp. 428-437, 2011.

[47] Contreras A. Felipe, Gustabo A. Ramos, and María A. Ríos, "Methodology and Design of an Adaptive Overcurrent Protection for Distribution Systems with DG," International Journal of Engineering \& Technology IJET-IJENS, vol. 12, no. 4, pp. 128-136, August 2012.

[48] R. R. Ferreira, A. P. Grilo, J. C. Teixeira, and R. C. Santos, "Method for adaptive overcurrent protection of distribution systems with Distributed synchronous Generators," 2015 IEEE Power \& Energy Society General Meeting, Denver, CO, pp. 1-5, 2015.

[49] S. I. Jang, J. H. Choi, J. W. Kim, and D. M. Choi, "An adaptive relaying for the protection of a wind farm interconnected with distribution networks," 2003 IEEE PES Transmission and Distribution Conference and Exposition (IEEE Cat. No.03CH37495), Dallas, TX, USA, vol. 1, pp. 296-302, 2003.

[50] S. C. Hsieh, C. S. Chen, C. T. Tsai, C. T. Hsu, and C. H. Lin, "Adaptive relay setting for distribution systems considering operation scenarios of wind generators," IEEE Trans. Ind. Appl., vol. 50, no. 2, pp. 1356-1363, 2014.

[51] N. Ali, W. Ahmed, A. Khalique, R. Zuhaib, and J. Nauman, "Application of Adaptive Over Current Protection for Distributed Generation," International Journal of Scientific and Engineering Research, vol. 7, no. 9, pp. 1643-1646, September 2016.

[52] M. Baran and I. El-Markabi, "Adaptive over current protection for distribution feeders with distributed generators," IEEE PES Power Systems Conference and Exposition, 2004, New York, NY, vol. 2, pp. 715-719, 2004.

[53] H. Lin, J. M. Guerrero, C. Jia, Z. H. Tan, J. C. Vasquez, and C. Liu, "Adaptive overcurrent protection for microgrids in extensive distribution systems," IECON 2016 - 42nd Annual Conference of the IEEE Industrial Electronics Society, Florence, pp. 4042-4047, 2016.

[54] M. Awaad, S. F. Mekhamer, and A. Y. Abdelaziz, "Design of an adaptive overcurrent protection scheme for microgrids," International Journal Engineering, Science and Technology, vol. 10, no. 1, pp. 1-12, 2018.

[55] N. Tummasit, S. Premrudeepreechacharn, and N. Tantichayakorn, "Adaptive overcurrent protection considering critical clearing time for a microgrid system," 2015 IEEE Innovative Smart Grid Technologies - Asia (ISGT ASIA), Bangkok, pp. 1-6, 2015.

[56] F. Coffele, C. Booth, and A. Dyśko, "An Adaptive Overcurrent Protection Scheme for Distribution Networks," IEEE Transactions Power Delivery, vol. 30, no. 2, pp. 561-568, 2015.

[57] H. H. Zeineldin, H. M. Sharaf, D. K. Ibrahim, and E. E. D. A. El-Zahab, "Optimal protection coordination for meshed distribution systems with DG using dual setting directional over-current relays," IEEE Transaction Smart Grid, vol. 6, no. 1, pp. 115-123, 2015.

[58] K. A. Saleh, H. H. Zeineldin, A. Al-Hinai, and E. F. El-Saadany, "Optimal Coordination of Directional Overcurrent Relays Using a New Time-Current-Voltage Characteristic," in IEEE Transactions on Power Delivery, vol. 30, no. 2, pp. 537-544, April 2015.

[59] W. K. A. Najy, H. H. Zeineldin, and W. L. Woon, "Optimal Protection Coordination for Microgrids with Gridconnected and Islanded Capability," in IEEE Transactions on Industrial Electronics, vol. 60, no. 4, pp. 1668-1677, April 2013.

[60] A. Tjahjono et al., "Adaptive modified firefly algorithm for optimal coordination of overcurrent relays," in IET Generation, Transmission \& Distribution, vol. 11, no. 10, pp. 2575-2585, July 2017.

[61] M. Ojaghi, Z. Sudi, and J. Faiz, "Implementation of Full Adaptive Technique to Optimal Coordination of Overcurrent Relays," IEEE Transaction Power Delivery, vol. 28, no. 1, pp. 235-244, January 2013.

[62] A. M. Ibrahim, W. El-Khattam, M. ElMesallamy, and H. A. Talaat, "Adaptive protection coordination scheme for distribution network with distributed generation using ABC," Journal of Electrical Systems and Information Technology, vol. 3, no. 2, pp. 320-332, September 2016.

[63] H. Muda and P. Jena, "Real time simulation of new adaptive overcurrent technique for microgrid protection," 2016 Natl. Power Syst. Conf. NPSC 2016, pp. 3-8, 2017.

[64] S. Shen et al., "An Adaptive Protection Scheme for Distribution Systems with DGs Based on Optimized Thevenin Equivalent Parameters Estimation," IEEE Transaction Power Delivery, vol. 32, no. 1, pp. 411-419, 2017.

[65] D. S. Kumar, D. Srinivasan, and T. Reindl, "A Fast and Scalable Protection Scheme for Distribution Networks with Distributed Generation," IEEE Transaction Power Delivery, vol. 31, no. 1, pp. 67-75, 2016.

[66] F. B. Costa, A. Monti, and S. C. Paiva, "Overcurrent Protection in Distribution Systems with Distributed Generation Based on the Real-Time Boundary Wavelet Transform," IEEE Transaction Power Delivery, vol. 32, no. 1, pp. 462 473, 2017.

[67] M. Kavi, Y. Mishra, and M. Vilathgamuwa, "Morphological Fault Detector for Adaptive Overcurrent Protection in Distribution Networks With Increasing Photovoltaic Penetration," IEEE Trans. Sustain. Energy, vol. 9, no. 3, pp. 1021-1029, 2018. 


\section{BIOGRAPHIES OF AUTHORS}

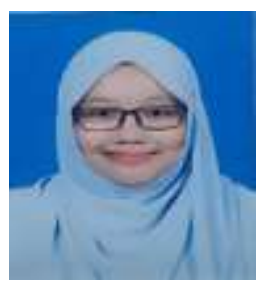

Nur Aisyah Mohd Yusof obtained Bachelor of Electrical Power Engineering (Hons.) in 2016 from Universiti Tenaga Nasional. She is currently pursuing a Master in Electrical Engineering at Universiti Tenaga Nasional. Her research interest included power system protection and smart grid.

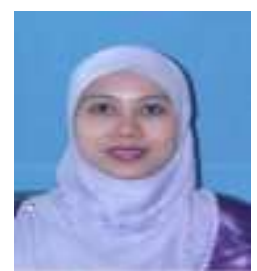

Dr. Zaipatimah Ali received Bachelor of Science in Electrical Engineering (BSEE) in 1998 from Purdue University, Indianapolis, US, Master of Science in Electrical and Computer Engineering (MSECE) in 2003 from the same university and Ph.D. in Electrical Engineering from University of Manchester, United Kingdom, in 2015. She is currently a Senior Lecturer at Department of Electrical Power Engineering, Universiti Tenaga Nasional (UNITEN). Her research interests include modeling, simulation, and fault diagnosis of electrical machines and drives as well as power system protection. She is a Member of the IEEE Signal Processing Society.

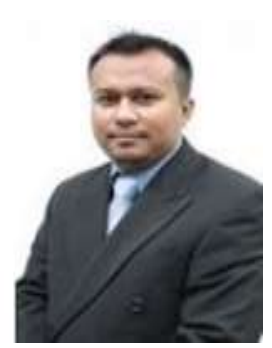

Profesor Ir. Dr. Mohd Zainal Abidin Ab Kadir received Bachelor of Electrical and Electronics Engineering in 2001 from Universiti Putra Malaysia and Ph.D. in High Voltage Engineering from University of Manchester, United Kingdom, in 2006. He is a Professor at CELP UPM and with the Faculty of Engineering, UPM. Currently, he serves as Strategic Hire Professor at Universiti Tenaga Nasional (The National Energy University) Malaysia. He is a WG Member of IEEE PES Lightning Performance on Overhead Lines and the Advisor of CELP, UPM. He is an Advisory Board Member for National Lightning Safety Institute (NLSI), USA and Local Convener of SC C4 of MNC-CIGRE. He is a Professional Engineer and a Chartered Engineer, as well as member of IEM, IEEE, IET, CIGRE. He is also an IEEE PES Distinguished Lecturer. 